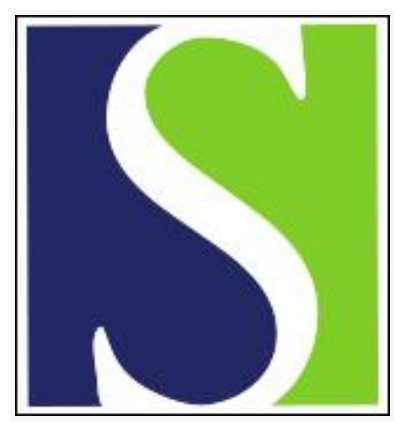

Scand J Work Environ Health 1995;21(6):450-459

https://doi.org/10.5271/sjweh.61

Issue date: Dec 1995

\title{
Cancer risk among workers in biomedical research
}

by Cordier S, Mousel M-L, Le Goaster C, Gachelin G, Le Moual N, Mandereau L, Carrat F, Michaud G, Hémon D

The following articles refer to this text: 2004;30(3):234-240;

2006;32(4):294-299; 2011;37(2):120-128; 2011;37(4):298-306;

2011;37(5):394-401; 2011;37(6):502-511

Key terms: bone sarcoma; brain tumor; epidemiologic study; laboratory; microbial genetics; molecular biology; non-Hodgkin's lymphoma; pancreatic cancer

This article in PubMed: www.ncbi.nlm.nih.gov/pubmed/8824751

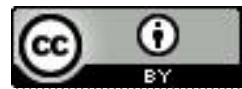




\title{
Cancer risk among workers in biomedical research
}

\author{
by Sylvaine Cordier, PhD, ${ }^{1}$ Marie-Laurence Mousel, MD, ${ }^{2}$ Corinne Le Goaster, MD, ${ }^{1}$ \\ Gabriel Gachelin, PhD, ${ }^{3}$ Nicole Le Moual, BSc, ${ }^{1}$ Laurence Mandereau, BSc, ${ }^{1}$ \\ Fabrice Carrat, MD, ${ }^{1}$ Gérard Michaud, PhD, ${ }^{4}$ Denis Hemon, PhD'
}

Cordier S, Mousel M-L, Le Goaster C, Gachelin G, Le Moual N, Mandereau L, Carrat F, Michaud G, Hemon D. Cancer risk among workers in biomedical research. Scand J Work Environ Health 1995:21:450-9.

\begin{abstract}
Objective This epidemiologic study was undertaken after a cluster of five cases of rare forms of cancer (bone sarcoma, non-Hodgkin's lymphoma) had been observed among biomedical research workers at the Pasteur Institute in Paris to ascertain whether their disease was connected with exposure during this research.

Methods A mortality study included 3765 people who worked at the Pasteur Institute between 1971 and 1986 and were followed until the end of 1987. Within this cohort a nested case-referent study included 23 cases of cancer [non-Hodgkin's lymphoma (6), multiple myeloma (1), leukemia (3), pancreatic cancer (7), bone cancer (3), brain tumor (3)], and four referents per case, matched for gender and year of birth.

Results Total mortality from cancer was less than expected, the standardized mortality ratio (SMR) being 72 for the men and 82 for the women. Among the women the proportion of pancreatic cancer cases was larger than expected [SMR 490, 95\% confidence interval (95\% CI) 158-1144], as was the number of brain cancer cases (SMR 239, 95\% CI 48 -696). Among the men, mortality from bone cancer was greater than expected (SMR $553,95 \%$ CI 62-2006). In the nested case-referent study, more cases than referents had worked in the areas of molecular biology [odds ratio (OR) 7.1, 95\% CI 1.5-33] and microbial genetics (OR 6.7, 95\% CI 1.3-35). These cases especially included non-Hodgkin's lymphoma and bone cancer. Associated with this finding was the fact that more cases had used certain chemicals, including ethidium bromide, acrylamide, methylnitronitrosoguanidine and ethylmethanesulfonate, and radioactive compounds (essentially ${ }^{32}$ phosphorus).

Conclusions As the products used are potent genotoxicants, the present findings suggest that work in biomedical research might well involve an increased risk of certain types of cancer; this conclusion should be balanced by the fact that two of the five index cases were included in the mortality study and four in the nested casereferent study.
\end{abstract}

Key terms bone sarcoma, brain tumor, epidemiologic study, laboratory, microbial genetics, molecular biology, non-Hodgkin's lymphoma, pancreatic cancer.

Workers engaged in biomedical research are exposed to a variety of potentially harmful chemical, physical, or biological agents. The types of exposure these workers undergo differs from that characterizing other occupational environments in several respects. First, they include many agents known for their genotoxic action. Second, the combined or individual toxicity of these agents for humans may not have been fully appreciated, and adequate decontamination or destruction techniques are not always available or routinely used. Finally, the environment of biomedical research is affected by rapid changes in techniques, due especially to the develop- ment of molecular biology, and by the consequent changes in the products used. These characteristics, combined with a very competitive work environment, explain why the objective surveillance of work conditions, essentially based on the degree of compliance to "good laboratory practices," is extremely difficult. Consequently, there is some apprehension about the effects of the aforementioned exposures on the health of laboratory workers (1).

Chemists and certain laboratory workers are the groups with work environments that come closest to those in biomedical research. Cohorts of such workers

1 Institut National de la Santé et de la Recherche Médicale (INSERM, Institute for Health and Medical Research), Villejuif, France.

2 Institut Pasteur - Médecine du Travail, Paris, France.

3 Institut Pasteur - Unité de Biologie moléculaire du gène, Paris, France.

4 Institut Pasteur - Service Hygiène et Sécurité, Paris, France.

Reprint requests to: Dr Sylvaine Cordier, INSERM U.170 16 Avenue Paul Vaillant-Couturier, 94807 Villejuif, Cedex — France. 
have been studied in the United States $(2-8)$, in the United Kingdom (9-12), Sweden (13), Italy (14), and Ireland (15). The most recent studies show that the overall mortality caused by cancer among these workers is lower than among the general population. Nevertheless, certain specific cancer sites have repeatedly been found to occur more frequently in these cohorts. They include lymphatic and hematopoietic cancer in general $(2,4,6$, $8,9,11-14$ ) and lymphosarcoma in particular, as well as brain tumors $(5,9-11,13,15)$, for which findings have been supported by case reports of brain tumor clusters among laboratory workers $(16,17)$. Less consistent excesses have also been observed for pancreatic cancer $(2,4,13,14)$ and melanoma $(3,12)$ and bone cancer (11).

In 1986, it was reported that five young (under 50) biologists working at the Pasteur Institute in Paris had developed cancer between 1981 and 1984. They comprised two cases of lymphoma, two of bone sarcoma, and one of adenocarcinoma of unknown origin (18). Two were dead by the time of the report. This prompted the establishment of a committee to determine whether these cancer cases had been occupationally induced. Its initial investigations produced the following preliminary conclusions: (i) apart from being molecular biologists, the five workers had no obvious common activity distinguishing them from other biologists, such as the manipulation of oncogenic viruses, and (ii) many of the agents with which they had been in contact were present in other laboratories in the Institute, so that any comprehensive survey of cancer and occupational exposure should necessarily include the entire institute. The questions which then remained to be answered were the following: (i) is there indeed an excess of cancer morbidity at the Pasteur Institute compared with the general population and (ii) if there is an excess for certain cancer sites, can this excess be explained by a particular occupational exposure or work environment? Because of a lack of incidence data, the first question was addressed by a mortality study despite the fact that the incidence of several of the suspected cancer sites such as lymphomas is not well measured by mortality. The second question was answered by a nested case-referent study with a detailed retrospective evaluation of occupational exposure.

\section{Subjects and methods}

\section{Study population}

The study population included all subjects who had worked at the Pasteur Institute in Paris for at least six months between 1 January 1971 and 31 December 1986. Workers at the Institute have very different administra- tive status, as they are sometimes connected with other institutions also, such as universities or public research institutes, or they may have been awarded research fellowships. Several sources were used to identify members of the cohort: Institute employee records, Institute records for students and fellows, and the administrative archives of the two main public research institutes in France (National Center for Scientific Research, National Institute for Health and Medical Research). In addition, past and present directors of laboratories of the Institute were asked to provide a list of the people who had worked in their laboratory during the period studied. Non-French citizens were excluded from the cohort because they would be difficult to trace. In all, 3765 people were identified (1518 men and 2247 women).

\section{Questionnaire}

A questionnaire designed to ascertain past occupational exposures and health status was mailed to each member of the cohort. Subjects were asked to state their lifetime occupational history before and while working at the Institute, the name of the laboratory or department in which they worked during the period studied, their function in that laboratory or department (scientist, student, engineer, technician, laboratory assistant, maintenance worker or office worker), the percentage of time they spent there, and the dates and the type of research they were doing. A check list of key words was also given so that all the different areas of biomedical research (microbiology, virology, biochemistry, molecular biology, etc) could be identified in which they had worked and the corresponding dates. Scientists, students, engineers, or technicians using specific techniques were asked to indicate, on a list, the chemicals, type of radiation, and biological agents with which they might have been in contact, together with the frequency of exposure (occasional, at least once a week, or every day) and the dates of exposure. The list included compounds which had been in use for the past 40 years in biomedical research. The chemicals included solvents (eg, benzene or formamide), alkylating agents (eg, acrylamide or formaldehyde), intercalating agents (eg ethidium bromide, acridine orange) and promoting agents, aromatic amines and heavy metals. Biological agents included oncogenic or other viruses, bacteria, parasites, fungi, cell cultures, human biological samples, laboratory animals and recombinant DNA (deoxyribonucleic acid). Every radioactive compound handled was recorded. Last, subjects were given a list of laboratory techniques covering the whole range of past and present biomedical research and were asked to indicate which ones they had used, and when.

Altogether 3765 questionnaires were sent out in three mailings, 2062 answers were received (55\%), 783 people $(21 \%)$ could not be traced (undelivered mail), and 
$920(25 \%)$ did not answer (refusal, deceased, or possible nonreceipt of mail).

\section{Administrative records}

For all the 1703 subjects for whom no answers were received, the name of the laboratory in which they had worked, the dates, and their job category (scientist, technician, etc) were obtained from the administrative records. No information was available about where these subjects worked before entering the Institute.

\section{Health status}

The questionnaire included items concerning general health status. The subjects were asked about their reproductive history, their history of infectious diseases such as tuberculosis and hepatitis, history of other serious diseases including high blood pressure, diabetes and cancer, history of surgery, hospitalization or long-term drug treatment, and family medical history.

\section{Mortality study}

For all the subjects who did not answer the questionnaire, vital status on 31 December 1987 was obtained by writing to the administration in charge of civil records at their birth place. For all the deceased, we obtained the date and place of death. For 66 persons $(0.2 \%)$ most of whom were born outside France, we were unable to obtain information on vital status. Information on the medical cause of death was obtained by linking our information about each decedent (gender, date and place of birth, and date and place of death) with the anonymous data base recording all the deaths that occur in France, together with their medical causes. This data base was designed to provide annual mortality statistics and is totally anonymous. For 123 of the 145 deaths in our cohort $(85 \%)$ the causes were retrieved in a unique manner by record linkage. For the remaining 22 deaths, it was not possible to find a correct match, even by investigating a period of up to one month before and after the reported date of death. For these 22 deaths, and for the deaths classified as resulting from an unknown cause, additional inquiries were made by the Institute's occupational health physician. We obtained the date, place of death, and medical cause for 11 of these deaths, complementary information for six (classified as "unknown cause" or "cancer, unspecified") and confirmation of two deaths among persons with previous unknown vital status. Person-years of follow-up were computed using the PERSON-YEARS computer program (19) between the date of entry (1 July 1971 or, if later, the date of entry into work at the Institute plus 6 months) and the end of follow-up (31 December 1987, date of death, or date of last information) according to gender, five-year age group, and calendar year between 1971 and 1987 (16044 person-years for the men and 24490 for the women). The expected numbers of deaths were computed for each cancer site, and for groups of conditions, on the basis of the national death rates. Standardized mortality ratios (SMR) were computed and their significance was tested using the one-sided Poisson test. Approximate confidence intervals were computed for the SMR values according to the formula described by Checkoway (20)

\section{Nested case-referent study}

For a detailed study of occupational exposures, and in order to include known incident cases of cancer, a casereferent study nested within the total cohort of 3765 subjects was performed. The cases were all subjects identified as having had one of the following diagnoses: nonHodgkin's lymphoma [International Classification of Diseases (ICD), ninth revision, 200, 202), Hodgkin's disease (ICD 201), multiple myeloma (ICD 203), leukemia (ICD 204-208), pancreatic cancer (ICD 157), bone cancer (ICD 170), or brain tumor (ICD 191, 239.6). These types of cancer were chosen a priori as having been linked in some instances with the work environment of chemists and laboratory workers $(1-17)$. Cases of decedents $(\mathrm{N}=17)$ were identified from death certificates, and incident cases $(\mathrm{N}=6)$ were gathered from the answers the questionnaire, or from occupational medical records for those who had a file in 1987 but had not answered the questionnaire. In this way we obtained medical information for $66 \%$ of the cohort members. All the diagnoses identified from the questionnaires were confirmed. In all, 23 cases were included in the casereferent study. They comprised six cases of non-Hodgkin's lymphoma, one case of multiple myeloma, three cases of leukemia, seven cases of pancreatic cancer, three cases of bone cancer, and three cases of brain tumor. For each case, four referents were randomly drawn from a set of eligible referents in the cohort; they were matched for gender, and date of birth ( \pm 5 years) and belonged to the cohort at the time of diagnosis or death of the case.

For the 115 subjects ( 23 cases and 92 referents) a detailed occupational history since their entry into employment at the Pasteur Institute was reconstructed from the following sources: questionnaire, scientific publications, and interviews of colleagues. The subjects were classified into the following three groups: unexposed (mainly administrative workers or workers involved in services like the library, photography department, etc); occasionally exposed (laboratory assistants essentially concerned with cleaning or maintenance); and regularly exposed (mainly scientists, technicians, engineers, and students regularly using certain techniques). Agreement was reached between a group of five experts (including physicians, chemists, and biologists) in defining the products with which these people might have been in contact in their laboratory. Areas of research and contact with 
radioactive materials were assessed for all three groups. Only for the regularly exposed group (group 3) did the experts define the products they were likely to have handled and the laboratory techniques they might have used from an a priori list included in the study questionnaire.

For each type of research or product handled, odds ratios adjusted for age and gender and their confidence intervals were estimated using logistic regression (21). When the numbers were too small, exact conditional maximum likelihood estimates of the odds ratio and confidence intervals corrected for mid-p were computed with StatXact Software for exact nonparametric inference (22).

\section{Results}

\section{Mortality study}

The distribution of the 3765 subjects by type of work at the Pasteur Institute is presented in table 1.

Table 2 shows that the total mortality for both the men and women was below the expected level, as was the mortality from cancer among the men. However, among selected types of cancer (table 2), the number of deaths observed from cancer of the pancreas exceeded the number expected for the women (SMR 490 95\% CI
158-1144), as did the number of deaths from bone cancer among the men (SMR $55395 \%$ CI 62-2006). Mortality due to brain tumors was also higher than expected for the women, although not significantly so. Among the other cancer sites (table 2), the number of lung cancer deaths observed for the men was significantly smaller than expected. Excluding subjects involved exclusively in clerical work did not modify these results.

\section{Nested case-referent study}

The sociodemographic characteristics of the cases and referents (table 3) show that they were closely matched for gender and year of birth. Seventy-four percent of the cases had died by the time of the present survey, but only

Table 1. Types of positions held by the people who worked at the Pasteur Institute between 1971 and 1986.

\begin{tabular}{|c|c|c|c|c|}
\hline \multirow[t]{2}{*}{$\begin{array}{l}\text { Last job category } \\
\text { at the Institute }\end{array}$} & \multicolumn{2}{|c|}{$\begin{array}{c}\text { Men } \\
(N=1518)\end{array}$} & \multicolumn{2}{|c|}{$\begin{array}{l}\text { Women } \\
(N=2247)\end{array}$} \\
\hline & N & $\%$ & N & $\%$ \\
\hline Administration & 169 & 11.2 & 568 & 25.3 \\
\hline Scientist, student & 695 & 46.2 & 554 & 24.7 \\
\hline Technician, engineer & 245 & 16.3 & 610 & 27.2 \\
\hline Laboratory assistant & 175 & 11.6 & 361 & 16.1 \\
\hline Maintenance worker & 131 & 8.7 & 125 & 5.6 \\
\hline Others & 91 & 6.0 & 28 & 1.2 \\
\hline Unknown & 12 & . & 1 & 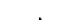 \\
\hline
\end{tabular}

Table 2. Observed $(0)$ and expected $(E)$ deaths from cancer among a cohort of biomedical research workers at the Pasteur Institute.

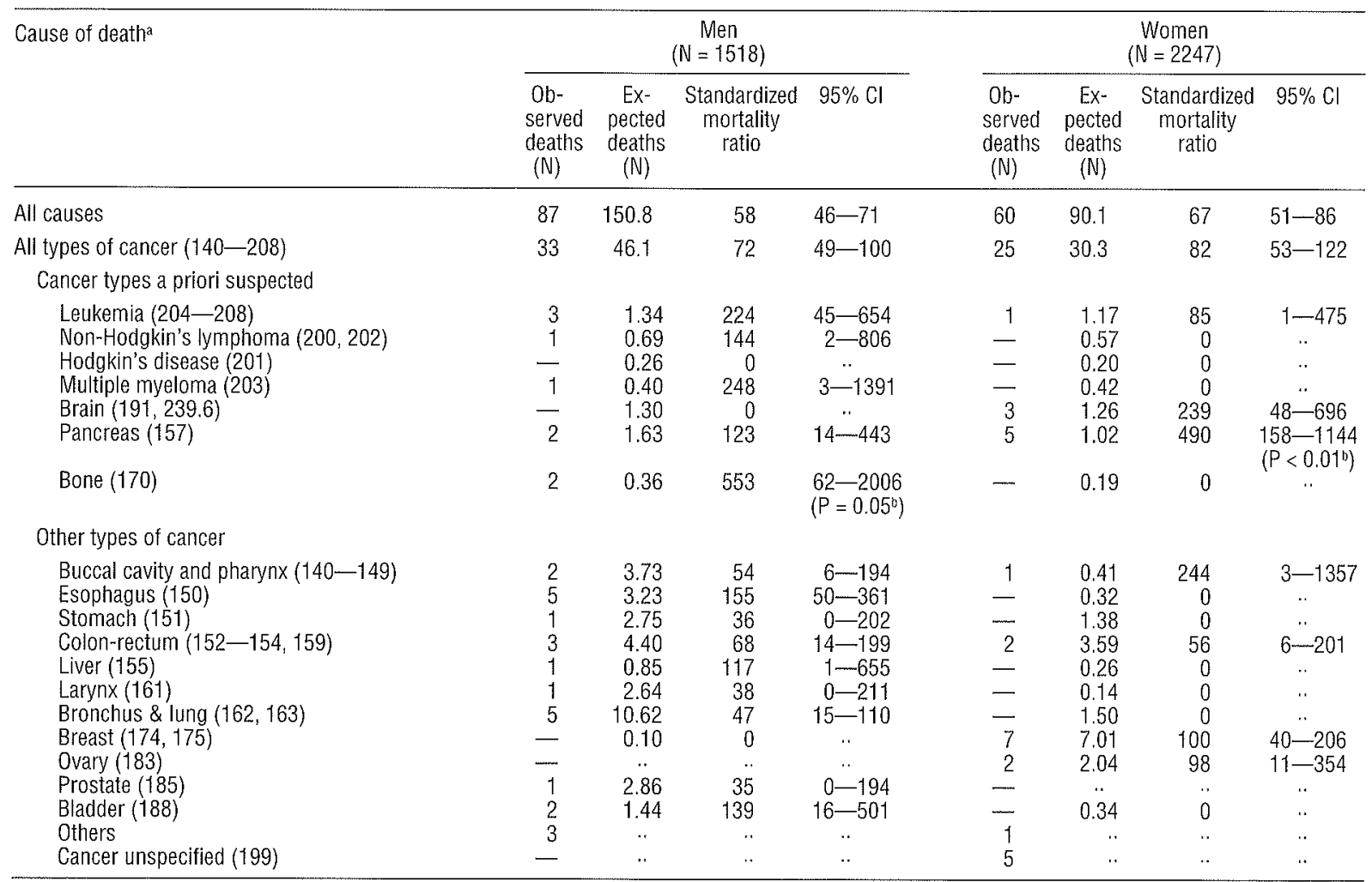

a Code of the International Classification of Diseases, ninth revision, in parentheses.

b One-sided Poisson test. 
Table 3. Sociodemographic characteristics of the cases and referents included in the case-referent study.

\begin{tabular}{|c|c|c|c|c|}
\hline \multirow[t]{2}{*}{ Characteristic } & \multicolumn{2}{|c|}{$\begin{array}{c}\text { Cases } \\
(\mathrm{N}=23)\end{array}$} & \multicolumn{2}{|c|}{$\begin{array}{c}\text { Referents } \\
(\mathrm{N}=92)\end{array}$} \\
\hline & N & $\%$ & N & $\%$ \\
\hline \multicolumn{5}{|l|}{ Gender } \\
\hline Male & 12 & 52.2 & 48 & 52.2 \\
\hline Female & 11 & 47.8 & 44 & 47.8 \\
\hline \multicolumn{5}{|l|}{ Year of birth } \\
\hline Before 1915 & 7 & 30.4 & 29 & 31.5 \\
\hline $1915-1940$ & 11 & 47.8 & 43 & 46.7 \\
\hline After 1940 & 5 & 21.7 & 20 & 21.7 \\
\hline \multicolumn{5}{|l|}{ Vital status ${ }^{a}$} \\
\hline Alive with questionnaire & 6 & 26.1 & 59 & 64.1 \\
\hline Alive without questionnaire & 0 & & 24 & 26.1 \\
\hline Dead & 17 & 73.9 & 9 & 9.8 \\
\hline \multicolumn{5}{|l|}{ Last job category } \\
\hline Administration & 4 & 17.4 & 17 & 18.5 \\
\hline Scientist, student & 7 & 30.4 & 25 & 27.2 \\
\hline Technician, engineer & 6 & 26.1 & 19 & 20.7 \\
\hline Laboratory assistant & 5 & 21.7 & 16 & 17.4 \\
\hline Maintenance worker & - & - & 11 & 12.0 \\
\hline Others & 1 & 4.3 & 4 & 4.3 \\
\hline
\end{tabular}

a On 31 December 1987.
$10 \%$ of the referents. Although the percentage of scientists and technicians was slightly higher among the cases than among the referents ( 56.5 versus $47.9 \%$ ), there was no statistically significant difference between the two groups.

Forty areas of research have been defined within the field of biomedical research; of these, microbial genetics and molecular biology were the two areas in which significantly more cases than referents had worked (table 4). When this comparison was restricted to the regularly exposed group, the same areas of research were present in the work history of significantly more of the cases than the referents.

As regards the exposure of the group regularly exposed a priori to chemicals (group 3: mainly scientists, technicians and students) more cases than referents used alkylating and intercalating agents in general (table 5). This exposure applied more specifically to methyl-nitronitrosoguanidine (MNNG) and ethyl methanesulfonate (EMS) among the alkylating agents and to ethidium bro-

Table 4. Areas of biomedical research in which the cases and referents in the nested case-referent study worked.

\begin{tabular}{|c|c|c|c|c|c|c|}
\hline \multirow[t]{2}{*}{ Area of research } & \multicolumn{2}{|c|}{$\begin{array}{c}\text { Cases } \\
(\mathbb{N}=23)\end{array}$} & \multicolumn{2}{|c|}{$\begin{array}{l}\text { Referents } \\
(\mathrm{N}=92)\end{array}$} & \multirow[t]{2}{*}{$\begin{array}{l}\text { Odds } \\
\text { ratio }^{\mathrm{a}}\end{array}$} & \multirow{2}{*}{$\begin{array}{c}95 \% \\
\text { confidence } \\
\text { interval }\end{array}$} \\
\hline & $N$ & $\%$ & $N$ & $\%$ & & \\
\hline General microbiology & 10 & 43.5 & 25 & 28.3 & 2.8 & $1.0-7.9$ \\
\hline Microbial genetics & 4 & 17.4 & 3 & 3.3 & 6.7 & $1.3-35$ \\
\hline Medical bacteriology & 9 & 39.1 & 24 & 26.1 & 1.9 & $0.7-5$ \\
\hline Microbial physiology & 4 & 17.4 & 8 & 8.7 & 2.2 & $0.6-8.3$ \\
\hline Toxins & 3 & 13.0 & 5 & 5.4 & 3.0 & $0.6-15$ \\
\hline Vaccines & 9 & 39.1 & 24 & 26.1 & 1.9 & $0.7-5.1$ \\
\hline Antibiotics & - & . & 8 & 8.7 & $\cdot$ & . \\
\hline Mycology & - & . & 3 & 5.3 & . & . \\
\hline Parasitology & 2 & 8.7 & 4 & 4.4 & 2.1 & $0.4-13$ \\
\hline Animal virology & 2 & 87 & 13 & 14.1 & 0.6 & $0.1-2.8$ \\
\hline Human virology & 3 & 13.0 & 16 & 17.4 & 0.7 & $0.2-2.8$ \\
\hline Animal genetics & 1 & 4.4 & - & & $\cdot$ & \\
\hline Biochemistry & 4 & 17.4 & 19 & 20.7 & 0.8 & $0.2-2.7$ \\
\hline Physicochemistry of proteins & 3 & 13.0 & 8 & 8.7 & 1.6 & $0.4-6.7$ \\
\hline Physicochemistry of nucleic acids & 2 & 8.7 & 1 & 1.1 & 9.1 & $0.7-111$ \\
\hline Lipid biochemistry & $\overline{1}$ & 4.4 & 6 & 6.5 & 0.7 & $0.1-5.9$ \\
\hline Polysaccharide biochemistry & - & $\cdot$ & 4 & 4.4 & & . \\
\hline Organic chemistry & - & & 4 & 4.4 & & \\
\hline Anatomopathology & 1 & 4.4 & 6 & 6.5 & 0.6 & $0.1-5.9$ \\
\hline Microscopy & 1 & 4.4 & 7 & 7.6 & 0.5 & $0.1-4.9$ \\
\hline Medicine & 2 & 8.7 & 8 & 8.7 & 1.0 & $0.2-5.2$ \\
\hline Allergology & - & $\cdot$ & 1 & 1.1 & . & . \\
\hline Cellular biology & 3 & 13.0 & 6 & 6.5 & 2.3 & $0.5-11$ \\
\hline Neurobiology & - & $\therefore$ & 2 & 2.2 & $\cdot$ & . \\
\hline Animal physiology & 2 & 8.7 & 3 & 3.3 & 2.8 & $0.4-18$ \\
\hline Biotechnology & 1 & 4.4 & 1 & 1.1 & 4.8 & $0.2-97$ \\
\hline Cellular differentiation & - & . & 3 & 3.3 & . & . \\
\hline Transgenes & - & . & 1 & 1.1 & . & . \\
\hline Blood transfusion & - & . & 4 & 4.4 & . & . \\
\hline Carcinogenesis & - & . & 2 & 2.2 & . & . \\
\hline Hybridomas & 1 & 4.4 & $\overline{1}$ & 1.1 & 4.3 & $0.2-79$ \\
\hline Molecular biology & 6 & 26.1 & 7 & 7.6 & 7.1 & $1.5-33$ \\
\hline Immunopathology & - & . & 2 & 2.2 & , & . \\
\hline Radioimmunology & - & . & 4 & 4.4 & . & . \\
\hline Immunoenzymology & - & . & 5 & 5.4 & . & . \\
\hline Immunogenetics & 1 & 4.4 & 1 & 1.1 & 4.6 & $0.2-92$ \\
\hline Cellular immunology & 1 & 4.4 & 2 & 2.2 & 2.1 & $0.2-28$ \\
\hline Nonspecific immunity & - & $\cdot 7$ & 3 & 3.3 & 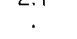 & $\cdot 20$ \\
\hline mmunochemistry & 1 & 4.4 & 7 & 7.6 & 0.6 & $0.1-4.8$ \\
\hline Maintenance & 1 & 4.4 & 9 & 9.8 & 0.4 & $0.0-3.6$ \\
\hline
\end{tabular}

a Adjusted for age and gender. 
Table 5. Distribution of the cases and referents according to potential exposure to chemicals (group regularly exposed: scientists, technicians and students only).

\begin{tabular}{|c|c|c|c|c|c|c|}
\hline \multirow[t]{2}{*}{ Chemical } & \multicolumn{2}{|c|}{$\begin{array}{c}\text { Cases } \\
(N=14)\end{array}$} & \multicolumn{2}{|c|}{$\begin{array}{c}\text { Referents } \\
(N=44)\end{array}$} & \multirow[t]{2}{*}{$\begin{array}{l}\text { Odds } \\
\text { ratio }\end{array}$} & \multirow{2}{*}{$\begin{array}{c}95 \% \\
\text { confidence } \\
\text { interval }\end{array}$} \\
\hline & $N$ & $\%$ & $N$ & $\%$ & & \\
\hline Solvents & 10 & 71.4 & 36 & 81.8 & 0.5 & $0.1-2.1$ \\
\hline $\begin{array}{l}\text { Benzene } \\
\text { Chlorinated solvents } \\
\text { Dioxane } \\
\text { Formamide } \\
\text { Toluene } \\
\text { Xylene } \\
\text { Others }\end{array}$ & $\begin{array}{l}3 \\
8 \\
2 \\
5 \\
8 \\
2 \\
3\end{array}$ & $\begin{array}{l}21.4 \\
57.1 \\
15.4 \\
35.7 \\
57.1 \\
14.3 \\
21.4\end{array}$ & $\begin{array}{r}20 \\
21 \\
7 \\
10 \\
33 \\
26 \\
9\end{array}$ & $\begin{array}{l}46.5 \\
47.7 \\
16.3 \\
23.3 \\
75.0 \\
59.1 \\
21.4\end{array}$ & $\begin{array}{l}0.3 \\
1.6 \\
0.8 \\
2.1 \\
0.4 \\
0.1 \\
1.0\end{array}$ & $\begin{array}{l}0.1-1.3 \\
0.4-5.8 \\
0.1-5.8 \\
0.5-9 \\
0.1-1.5 \\
0.0-0.6 \\
0.2-4.5\end{array}$ \\
\hline Alkylating agents & 11 & 78.6 & 22 & 51.2 & 4.5 & $1-20.7$ \\
\hline $\begin{array}{l}\text { Nitrosamines } \\
\text { Methyl-nitrosoguanidine } \\
\text { Ethyl methanesulfonate } \\
\text { Dimethyl sulfate } \\
\text { Chloromethylethers } \\
\text { Acrylamide } \\
\text { Aflatoxins } \\
\text { Aziridine } \\
\text { Formaldehyde } \\
\text { Hydrazine }\end{array}$ & $\begin{array}{r}1 \\
3 \\
4 \\
1 \\
7 \\
1 \\
7 \\
2\end{array}$ & $\begin{array}{r}7.1 \\
21.4 \\
28.6 \\
7.1 \\
5 \\
50.0 \\
7.1 \\
50.0 \\
15.4\end{array}$ & $\begin{array}{r}- \\
1 \\
1 \\
1 \\
11 \\
1 \\
15 \\
2\end{array}$ & $\begin{array}{r}2.3 \\
2.3 \\
2.3 \\
25.6 \\
. \\
2.3 \\
34.9 \\
5.0\end{array}$ & $\begin{array}{c}\infty^{b} \\
\infty^{b} \\
19.5^{b} \\
4.7^{b} \\
0.0^{b} \\
4.2 \\
\infty^{b} \\
0.0^{b} \\
2.0 \\
4.3\end{array}$ & $\begin{array}{l}0.1-\infty \\
3.0-\infty \\
2.1-532 \\
0.3-91 \\
0.0-36 \\
0.9-19 \\
0.3-\infty \\
0.0-36 \\
0.6-7.1 \\
0.5-37\end{array}$ \\
\hline Intercalating agents & 6 & 42.9 & 8 & 18.6 & 4.1 & $1.0-17.7$ \\
\hline $\begin{array}{l}\text { Acridine orange } \\
\text { Ethidium bromide } \\
\text { Ethidium propyl EDTA } \\
\text { lodinated propidium } \\
\text { Methidium propyl EDTA }\end{array}$ & $\begin{array}{r}3 \\
6 \\
- \\
- \\
-\end{array}$ & $\begin{array}{c}21.4 \\
42.9 \\
\cdot \\
.\end{array}$ & $\begin{array}{l}3 \\
7 \\
1 \\
1 \\
1\end{array}$ & $\begin{array}{r}7.0 \\
16.3 \\
2.3 \\
2.3 \\
2.3\end{array}$ & $\begin{array}{l}4.3 \\
5.4 \\
0.0^{\mathrm{b}} \\
0.0^{\mathrm{b}} \\
0.0^{\mathrm{b}}\end{array}$ & $\begin{array}{l}0.7-27 \\
1.1-26 \\
0.0-36 \\
0.0-36 \\
0.0-36\end{array}$ \\
\hline Promoting agents & 6 & 42.9 & 20 & 45.5 & 0.9 & $0.3-3.4$ \\
\hline $\begin{array}{l}\text { Phorbol esters } \\
\text { Phenol } \\
\text { Hydrogen peroxide }\end{array}$ & $\begin{array}{l}- \\
5 \\
5\end{array}$ & $\begin{array}{l}42.9 \\
35.7\end{array}$ & $\begin{array}{r}2 \\
16 \\
14\end{array}$ & $\begin{array}{r}4.5 \\
36.4 \\
32.6\end{array}$ & $\begin{array}{l}0.0^{\mathrm{b}} \\
1.4 \\
1.2\end{array}$ & $\begin{array}{l}0.0-9.3 \\
0.4-4.9 \\
0.3-4.4\end{array}$ \\
\hline Aromatic amines & 2 & 14.3 & 7 & 16.3 & 0.7 & $0.1-4.5$ \\
\hline $\begin{array}{l}\text { Auramine } \\
\text { Benzidine } \\
\text { Diaminobenzidine } \\
\text { Ortho-phenylenediamine } \\
\text { Ortho-toluidine } \\
\text { Others }\end{array}$ & $\begin{array}{l}-1 \\
1 \\
1 \\
1\end{array}$ & $\begin{array}{l}7.1 \\
7.1 \\
7 \\
7.1 \\
7.1\end{array}$ & $\begin{array}{l}2 \\
1 \\
4 \\
4 \\
2 \\
1\end{array}$ & $\begin{array}{l}4.5 \\
2.3 \\
9.1 \\
9.1 \\
4.5 \\
2.3\end{array}$ & $\begin{array}{l}0.0^{\mathrm{b}} \\
2.9 \\
0.7 \\
0.0^{\mathrm{b}} \\
1.5 \\
2.7\end{array}$ & $\begin{array}{l}0.0-6.9 \\
0.1-58 \\
0.1-6.6 \\
0.0-2.5 \\
0.1-21 \\
0.1-54\end{array}$ \\
\hline Heavy metals & 1 & 7.1 & 5 & 11.4 & 0.6 & $0.1-5.7$ \\
\hline Other chemicals & 2 & 14.3 & 8 & 20.0 & 0.7 & $0.1-3.8$ \\
\hline
\end{tabular}

a Adjusted for age and gender.

- Exact odds ratio and mid-p corrected interval.

mide among the intercalating agents. In addition more cases used acrylamide or acridine orange, but the difference was not significant. Xylene was used by more referents than cases. Among the biological agents, recombinant DNAs were studied by more cases than referents (table 6). Among the radioactive materials, too, more cases were exposed to ${ }^{32}$ phosphorus.

The distributions of specific types of cancer among the cases according to selected research areas and occupational exposures, compared with the distribution among the whole group of referents, are presented in tables 7 and 8 . The distributions show that the excess risk of cancer in the case-referent study, in association with work in the area of microbial genetics and molecular biology, and with exposure to the agents involved, was mainly due to non-Hodgkin's lymphomas and bone cancer. Cases with brain tumors or pancreatic cancers more often worked in the area of general microbiology and medical bacteriology, but no specific exposure could be identified.

Four of the laboratory techniques used in biomedical research for the last 50 years were used by more cases than referents: the preparation of plasmids, the detection of nucleic acids, Maxam-Gilbert sequencing, and Sanger sequencing. An analysis of the subgroup with hematopoietic cancer also pointed to frequent use of the techniques involving liquid scintillation. No technique was specifically associated with the history of pancreatic cancer among the cases and their referents.

\section{Discussion}

These results seem to show that there has been a risk associated with specific cancer in the scientific community working at the Pasteur Institute in Paris. The cohort 
Table 6. Distribution of the cases and referents according to potential exposure to biological agents and radioactive material (group regularly exposed: scientist, technicians and students only).

\begin{tabular}{|c|c|c|c|c|c|c|}
\hline \multirow[t]{2}{*}{ Contact with biological agents } & \multicolumn{2}{|c|}{$\begin{array}{c}\text { Cases } \\
(N=14)\end{array}$} & \multicolumn{2}{|c|}{$\begin{array}{l}\text { Referents } \\
(N=44)\end{array}$} & \multirow[t]{2}{*}{$\begin{array}{l}\text { Odds } \\
\text { ratio }\end{array}$} & \multirow{2}{*}{$\begin{array}{c}95 \% \\
\text { confidence } \\
\text { interval }\end{array}$} \\
\hline & $N$ & $\%$ & $N$ & $\%$ & & \\
\hline Oncogenic viruses & 1 & 7.7 & 5 & 11.6 & 0.6 & $0.1-6.6$ \\
\hline Other viruses & 6 & 46.2 & 12 & 27.9 & 2.4 & $0.6-8.7$ \\
\hline Bacteria & 13 & 92.9 & 28 & 66.7 & 7.4 & $0.8-65$ \\
\hline Parasites & 3 & 25.0 & 8 & 19.1 & 1.2 & $0.2-6.2$ \\
\hline Fungi & 1 & 7.7 & 7 & 16.7 & 0.5 & $0.1-4.1$ \\
\hline Cell cultures (tumor) & 2 & 16.7 & 7 & 16.3 & 0.9 & $0.1-5.3$ \\
\hline Cell cultures (other) & $-\infty$ & . & 5 & 11.6 & $0.0^{\mathrm{b}}$ & $0.0-1.9$ \\
\hline Human biological samples & 6 & 42.9 & 22 & 52.4 & 0.5 & $0.1-2.0$ \\
\hline Laboratory animals & 10 & 71.4 & 37 & 84.1 & 0.4 & $0.1-1.8$ \\
\hline Recombinant DNA & 6 & 46.2 & 4 & 9.3 & $\infty^{b}$ & $3.7-\infty$ \\
\hline \multicolumn{7}{|l|}{ lonizing radiations } \\
\hline${ }^{32} \mathrm{P}$ (phosphorus) & 6 & 42.9 & 8 & 18.1 & 11.8 & $0.1-122$ \\
\hline${ }^{35} \mathrm{~S}$ (sulfur) & 4 & 28.6 & 5 & 14.0 & 3.7 & $0.7-18$ \\
\hline${ }^{3} \mathrm{H}$ (tritium) & 6 & 42.9 & 10 & 27.3 & 3.4 & $0.8-14$ \\
\hline 125| (iodine) & 2 & 14.3 & 8 & 18.2 & 0.6 & $0.1-6.1$ \\
\hline${ }^{14} \mathrm{C}$ (carbon) & 3 & 23.1 & 7 & 20.5 & 2.6 & $0.4-16$ \\
\hline$x$-rays & 1 & 7.1 & 1 & 2.3 & 3.0 & $0.2-54$ \\
\hline Others & - & . & 1 & 2.3 & $0.0^{\mathrm{b}}$ & $0.0-23$ \\
\hline At least one radioactive compound & 7 & 50.0 & 18 & 40.9 & 1.6 & $0.4-6.4$ \\
\hline
\end{tabular}

a Adjusted for age and gender.

- Exact odds ratio and mid-p corrected interval.

Table 7. Distribution of the cases and referents according to selected research areas and exposures, by cancer type (lymphatic and hematopoietic). ( $\mathrm{CD}=$ International Classification of Diseases, ninth revision)

\begin{tabular}{|c|c|c|c|c|c|c|c|c|c|c|}
\hline & \multirow[t]{2}{*}{$\begin{array}{l}\text { Referents } \\
\quad(N)\end{array}$} & \multicolumn{3}{|c|}{$\begin{array}{l}\text { Non-Hodgkin's } \\
\text { Jymphoma } \\
\text { (|CD-9 200, 202) }\end{array}$} & \multicolumn{3}{|c|}{$\begin{array}{c}\text { Leukemiac } \\
\text { (ICD-9 204-208) }\end{array}$} & \multicolumn{3}{|c|}{$\begin{array}{l}\text { All lymphatic and } \\
\text { hematopoietic } \\
\text { (ICD-9200-208) }\end{array}$} \\
\hline & & Ne & $\begin{array}{l}\text { Odds } \\
\text { ratiof }\end{array}$ & $\begin{array}{l}95 \% \\
\text { confidence } \\
\text { interval }\end{array}$ & $\mathrm{Ne}^{\mathrm{e}}$ & $\begin{array}{l}\text { Odds } \\
\text { ratio }\end{array}$ & $\begin{array}{c}95 \% \\
\text { confidence } \\
\text { interval }\end{array}$ & $\mathrm{Ne}$ & $\begin{array}{l}\text { Odds } \\
\text { ratio }\end{array}$ & $\begin{array}{c}95 \% \\
\text { confidence } \\
\text { interval }\end{array}$ \\
\hline \multicolumn{11}{|l|}{ All subjects } \\
\hline General microbiology & 25 & - & - & $0-1.9$ & 1 & 1.5 & $0.1-19$ & 2 & 0.7 & $0.1-3.6$ \\
\hline $\begin{array}{l}\text { Microbial genetics } \\
\text { Molecular biology }\end{array}$ & $\begin{array}{l}3 \\
7\end{array}$ & $\begin{array}{l}2 \\
4\end{array}$ & $\begin{array}{l}13.8 \\
51.5\end{array}$ & $\begin{array}{l}1.5-125 \\
3.7-722\end{array}$ & $\begin{array}{l}1 \\
-\end{array}$ & $\begin{array}{c}14.8 \\
0\end{array}$ & $\begin{array}{c}1.0-223 \\
. .\end{array}$ & $\begin{array}{l}3 \\
4\end{array}$ & $\begin{array}{l}12.1 \\
12.6\end{array}$ & $\begin{array}{l}1.9-76 \\
1.9-86\end{array}$ \\
\hline Medical bacteriology & 24 & 1 & 0.6 & $0.1-6.1$ & - & 0 & .. & 1 & 0.3 & $0.0-2.9$ \\
\hline \multicolumn{11}{|l|}{ Subjects regularly exposed } \\
\hline $\begin{array}{l}\text { Solvents } \\
\text { Alkylating agents } \\
\text { Intercalating agents } \\
\text { Promoting agents }\end{array}$ & $\begin{array}{r}36 \\
22 \\
8 \\
20\end{array}$ & $\begin{array}{l}4 \\
4 \\
3 \\
3\end{array}$ & $\begin{array}{r}\infty \\
\infty \\
13.1 \\
3.6\end{array}$ & $\begin{array}{l}0.1-\infty \\
0.6-\infty \\
1.1-153 \\
0.3-40\end{array}$ & $\begin{array}{r}1 \\
1 \\
- \\
-\end{array}$ & $\begin{array}{c}\infty \\
\infty \\
0 \\
0\end{array}$ & $\begin{array}{c}0.1-\infty \\
0.1-\infty \\
. . \\
. .\end{array}$ & $\begin{array}{l}5 \\
6 \\
3 \\
3\end{array}$ & $\begin{array}{r}0.9 \\
\infty \\
4.1 \\
1.1\end{array}$ & $\begin{array}{l}0.1-10 \\
1.3-\infty \\
0.7-26 \\
0.2-6.4\end{array}$ \\
\hline $\begin{array}{l}\text { Methyl-nitrosoguanidine } \\
\text { Ethyl methanesulfonate } \\
\text { Acrylamide } \\
\text { Ethidium bromide } \\
\text { Recombinant DNA } \\
\text { 32Phosphorus }\end{array}$ & $\begin{array}{r}-1 \\
11 \\
7 \\
4 \\
8\end{array}$ & $\begin{array}{l}1 \\
2 \\
4 \\
3 \\
4 \\
4\end{array}$ & $\begin{array}{r}\infty \\
84.0 \\
\infty \\
15.4 \\
\infty \\
\infty\end{array}$ & $\begin{array}{l}0.6-\infty \\
3.4-2060 \\
1.7-\infty \\
1.3-182 \\
5.4-\infty \\
3.5-\infty\end{array}$ & $\begin{array}{r}1 \\
1 \\
- \\
- \\
-\end{array}$ & $\begin{array}{l}\infty \\
\infty \\
. . \\
0 \\
. . \\
. .\end{array}$ & $\begin{array}{c}0.9-\infty \\
0.9-\infty \\
. . \\
. . \\
. . \\
. .\end{array}$ & $\begin{array}{l}2 \\
3 \\
5 \\
3 \\
4 \\
4\end{array}$ & $\begin{array}{r}\infty \\
72.6 \\
19.8 \\
4.7 \\
29.8 \\
12.2\end{array}$ & $\begin{array}{l}2.2-\infty \\
3.2-\infty \\
1.3-314 \\
0.7-32 \\
2.2-405 \\
1.0-147\end{array}$ \\
\hline
\end{tabular}

a Number for all subjects $=92$; number for subjects reqularly exposed $=44$.

b Number for all subjects $=6$; number for subjects regularly exposed $=4$.

- Number for all subjects $=3$; number for subjects regularly exposed $=1$.

d Number for all subjects $=10$; number for subjects regularly exposed $=6$.

* Number exposed.

Adjusted for age and gender.

analysis mainly points to bone cancer among the men and cancer of the pancreas among the women. In the nested case-referent analysis, microbial genetics and molecular biology, together with the products and techniques used in these fields, were the two research areas associated with selected forms of cancer, mainly including non-Hodgkin's lymphoma and bone cancer. Except for work in the area of medical bacteriology, no form of potential exposure showed any association, among these cases and referents, with the larger than expected numbers of pancreatic cancer and brain tumors.

The results of this investigation raise several issues. First, it was initiated after the appearance of a report of a cluster of five cancer cases in a scientific community, 
Table 8. Distribution of the cases and referents according to selected research areas and exposures, by cancer type (bone, brain and pancreatic). (ICD-9 = International Classification of Diseases, ninth revision)

\begin{tabular}{|c|c|c|c|c|c|c|c|c|c|c|}
\hline & \multirow[t]{2}{*}{$\begin{array}{l}\text { Referentsa } \\
\quad(\mathrm{N})\end{array}$} & \multicolumn{3}{|c|}{$\begin{array}{l}\text { Bone cancerb } \\
\text { (ICD-9 170) }\end{array}$} & \multicolumn{3}{|c|}{$\begin{array}{c}\text { Brain tumorsc } \\
(\text { ICD-9 191, 239.6) }\end{array}$} & \multicolumn{3}{|c|}{$\begin{array}{c}\text { Pancreatic cancerd } \\
\text { (ICD-9 157) }\end{array}$} \\
\hline & & $\mathrm{Ne}^{\mathrm{e}}$ & $\begin{array}{l}\text { Odds } \\
\text { ratio }\end{array}$ & $\begin{array}{l}95 \% \\
\text { confidence } \\
\text { interval }\end{array}$ & $\mathrm{N}^{\mathrm{e}}$ & $\begin{array}{l}\text { Odds } \\
\text { ratiof }\end{array}$ & $\begin{array}{l}95 \% \\
\text { confidence } \\
\text { interval }\end{array}$ & $N^{e}$ & $\begin{array}{l}\text { Odds } \\
\text { ratiof }\end{array}$ & $\begin{array}{c}95 \% \\
\text { confidence } \\
\text { interval }\end{array}$ \\
\hline \multicolumn{11}{|l|}{ All subjects } \\
\hline General microbiology & 25 & 2 & 7.2 & $0.5-95$ & 2 & 9.4 & $0.7-124$ & 4 & 3.2 & $0.6-16$ \\
\hline $\begin{array}{l}\text { Microbial genetics } \\
\text { Molecular biology }\end{array}$ & $\begin{array}{l}3 \\
7\end{array}$ & $\begin{array}{l}1 \\
2\end{array}$ & $\begin{array}{l}10.2 \\
16.6\end{array}$ & $\begin{array}{l}0.6-176 \\
0.8-363\end{array}$ & $\begin{array}{l}0 \\
0\end{array}$ & $\begin{array}{l}0 \\
0\end{array}$ & $\begin{array}{l}. . \\
. .\end{array}$ & - & $\begin{array}{l}0 \\
0\end{array}$ & $\begin{array}{l}. . \\
. .\end{array}$ \\
\hline Medical bacteriology & 24 & 1 & 1.4 & $0.1-17$ & 2 & 5.7 & $0.5-69$ & 5 & 6.3 & $1.1-37$ \\
\hline \multicolumn{11}{|l|}{ Subjects regularly exposed } \\
\hline $\begin{array}{l}\text { Solvents } \\
\text { Alkylating agents } \\
\text { Intercalating agents } \\
\text { Promoting agents }\end{array}$ & $\begin{array}{r}36 \\
22 \\
8 \\
20\end{array}$ & $\begin{array}{l}2 \\
2 \\
2 \\
2\end{array}$ & $\begin{array}{l}\infty \\
\infty \\
\infty \\
\infty\end{array}$ & $\begin{array}{l}0.0-\infty \\
0.1-\infty \\
0.7-\infty \\
0.3-\infty\end{array}$ & $\overline{-}$ & $\begin{array}{l}0 \\
0 \\
0 \\
0\end{array}$ & $\begin{array}{l}. . \\
. . \\
. . \\
.\end{array}$ & $\begin{array}{l}3 \\
3 \\
1 \\
1\end{array}$ & $\begin{array}{l}0.4 \\
2.3 \\
1.4 \\
0.5\end{array}$ & $\begin{array}{l}0.6-4.3 \\
0.3-18 \\
0.1-18 \\
0.0-5.4\end{array}$ \\
\hline Methyl-nitrosoguanidine & - & 1 & $\infty$ & $0.7-\infty$ & - & .. & .. & - & .. & .. \\
\hline Ethyl methanesulphonate & 1 & 1 & $\infty$ & $0.6-\infty$ & - & 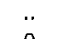 & .. & - & . & $\cdot$. \\
\hline Acrylamide & 11 & 2 & $\infty$ & $0.4-\infty$ & - & 0 &.. & - & 0 & . \\
\hline Ethidum bromide & 7 & 2 & $\infty$ & $0.7-\infty$ & 一 & 0 & .. & 1 & 3.0 & $0.2-46$ \\
\hline Recombinant DNA & 4 & 2 & $\infty$ & $0.7-\infty$ & - & 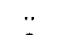 & $\cdot \cdot$ & - &.$\cdot$ & .' \\
\hline${ }^{32}$ Phosphorus & 8 & 2 & $\infty$ & $0.3-\infty$ & - & 0 & .. & - & 0 &.$\cdot$ \\
\hline
\end{tabular}

Number for all subjects $=92$; number for subjects regularly exposed $=44$.

- Number for all subjects $=3$; number for subjects regularly exposed $=2$.

- Number for all subjects $=3$; number for subjects regularly exposed $=1$.

d Number for all subjects $=7$, number for subjects regularly exposed $=5$.

Number exposed.

- Adjusted for age and gender.

and consequently the investigations were conducted, first, to confirm and define what constitutes an excess incidence of cancer and, second, to identify the specific forms of occupational exposure which might be associated with such an excess. Two of the five index cases were included in the mortality study, and four in the nested case-referent study for the specific types of cancer investigated.

As regards the mortality study, the potential biases are similar to those found in studies of this type. The tracing of vital status was almost complete $(99.8 \%)$, but only $85 \%$ of the causes of death could be identified through official records. The quality of the information on the death certificate was not always satisfactory by epidemiologic standards, and we suspect that, in general, some causes of death, such as bone neoplasms, may in fact have been secondary, and some types of cancer (pancreas and brain) were more likely to have been diagnosed and recorded among the higher socioeconomic classes than among the general population. The choice of the total French population as a reference was justified, since rare forms of cancer were involved. Nevertheless, our results are consistent with those of previous studies as regards the mortality from cancer among scientists potentially exposed to mixtures of chemicals, such as chemists or biologists $(1-17)$. The statistical power of the study only allowed the detection of high risks. Thus the minimum detectable relative risk was 3.6 for a disease with an annual incidence or mortality rate of 0.0001 $(\alpha=0.05, \beta=0.20$, one-sided test $)(23)$.
To investigate various types of occupational exposure in a nested case-referent study, we grouped together several types of cancer for which an excessively high incidence had at one time been observed in similar populations. This choice involved several limitations. Except perhaps for hematopoietic malignancies, these forms of cancer do not have a common etiology a priori, and the reason for their being observed in excess in similar populations might be connected with characteristics common to these populations, such as better access to medical care, dietary factors, and the like, rather than with occupational exposure. However, our choice did not preclude analyses specific for particular types of cancer, and it gathered numbers allowing more meaningful calculations.

Due to the absence of cancer registration in the Paris region, another potential problem arose from the fact that both the deceased and incident cases were ascertained for about $66 \%$ of the cohort only, by combining medical information from different sources (ie, death certificates, hospital records and occupational medicine). Using estimates of cancer incidence in France (24), we were able to calculate that for the total cohort 14 cases could be expected for the selected types of cancer, whereas we observed $23(\mathrm{P}<0.05)$. Therefore there is no obvious evidence that the number of cancer cases included in the nested case-referent study was greatly underestimated.

Occupational history was reconstructed from available documents by a group of scientists familiar with biomedical research and with the Pasteur Institute. For 
the case-referent study, detailed replies to the questionnaire were available for $64 \%$ of the referents and $26 \%$ of the cases, since many were deceased when the investigation started. All the items of information were checked, additional information was sought from subjects' colleagues at work, and, as far as possible, evaluations were done blindly in relation to case or referent status, except for the index cases $(\mathrm{N}=4)$, for whom very detailed information had been gathered. We took care to obtain precise and documented answers to a subset of questions concerning areas of research, an a priori list of chemicals, biological agents, radioactive materials, and an a priori list of laboratory techniques, and we believe that the information collected about these variables was not differently biased among the cases and referents in the sense of overestimating the relative risk. Due to the small numbers of subjects surveyed and to the incomplete information available about their work history before joining the Institute, no risk trend according to time variables could be estimated.

In the nested case-referent study, a large number of comparisons was made between the cases and referents concerning areas of research $(\mathrm{N}=40)$, chemical exposures $(N=38)$, biological agents $(N=10)$, and exposure to ionizing radiation $(\mathrm{N}=7)$, and some positive results might have arisen by chance. However, the patterns of positive results obtained are coherent between areas of research, chemicals, biological agents, and radioactive compounds (such as molecular biology, acrylamide, ethidium bromide, and ${ }^{32}$ phosphorus), and the three lists (chemicals, biological agents, and radioactive compounds) should be seen as refinements of the first list (areas of research) rather than as independent lists.

No known risk factor for the types of cancer investigation was taken into account as potential confounding factors. Apart from tobacco smoking for pancreatic cancer, they involved no strong nonoccupational risk factor which would bias the results if not taken into consideration. The information obtained from the questionnaires about the smoking habits of the scientific community at the Pasteur Institute showed that tobacco consumption was lower than the average for the French population, and this finding is reflected by the lower lung cancer risk in this cohort.

In summary, the results of the case-referent study show that more of the cases (mostly non-Hodgkin's lymphoma and bone cancer) had worked in the area of molecular biology than the referents. This finding no doubt explains why more cases had used certain chemicals such as acrylamide and ethidium bromide, biological agents like recombinant DNA, and radioactive products, chiefly ${ }^{32}$ phosphorus. The finding that more cases than referents had worked in the area of microbial genetics probably explains the fact that more had used MNNG and EMS. In addition, the restriction of the analysis to cases of hematopoietic cancer indicated that more cases than referents used liquid scintillation techniques. However, having worked in molecular biology does not explain why the numbers of pancreatic cancer and brain tumors were larger than expected, since none of the cases with these diseases had worked in this area. Many of them had worked in medical bacteriology, but no specific exposure could be associated with these excess numbers.

Our results showing an increased risk of non-Hodgkin's lymphoma agree with those of previous studies on cohorts of chemists or laboratory workers $(2,4,6,8$, $11-14)$. In addition, case-referent studies have suggested that occupational exposure to solvents might be a risk factor for non-Hodgkin's lymphoma $(25,26)$. Exposure to ionizing radiation, especially radium, is the only well-established occupational agent related to bone cancer (27).

An epidemiologic investigation cannot more precisely define the products or agents potentially responsible for causing cancer because many of these products are extremely specific and they are only used in experiments involving particular molecular biology techniques. They all interact with DNA and as such are plausible candidates for initiating or promoting a carcinogenic process. This finding suggests that certain hypotheses should be tested by biological investigations.

In conclusion, the observations made at the Pasteur Institute do not in themselves prove the existence of a causal relationship between the use of techniques relating to molecular biology or microbial genetics on one hand, and an excess number of lymphomas or bone cancer cases on the other. However, there are several good reasons for believing that such a relationship exists, and it must therefore be investigated in other contexts. The relationship is plausible because, during the initial period of research in these areas, large amounts of strongly genotoxic products were used. We believe that the present findings are definitely sufficient reason for strongly recommending the enforcement of safety measures in all the laboratories concerned.

\section{Acknowledgments}

We acknowledge financial support from the following: the Pasteur Institute, INSERM (National Institute of Health and Medical Research), Ministère de la Recherche (Ministry of Research), Direction Générale de la Santé (Ministry of Health), Direction des Relations du Travail (Ministry of Labor), Ligue Nationale contre le Cancer (National Ligue against Cancer), and GEFLUC (Group of French Companies against Cancer). 
We wish to thank the following: G Gareau, N Namiech, P Pollet from the Pasteur Institute; A Picot and JC Zerbib for their assistance in the evaluation of past occupational exposure; and F Hatton, E Michel, B Bonnet, F Pietri and $G$ Vasseur from the National Institute for Health and Medical Research (INSERM). We are grateful to Ms E Przybilski for typing the manuscript and to Ms M Dreyfus for revising the text.

\section{References}

1. Sasco AJ. Risques pour la santé dans les laboratoires de recherche biologique et médicale. Med Sci 1989;5:489—98.

2. Li FP, Fraumeni JF, Mantel N, Miller RW. Cancer mortality among chemists. JNCI 1969;43:1159—64.

3. Hoar SK, Pell S. A retrospective cohort study of mortality and cancer incidence among chemists. J Occup Med 1981;23: 485-94.

4. Walrath J, Li FP, Hoar SK, Mead MW, Fraumeni JF. Causes of death among female chemists. Am J Public Health 1985;75: 883-5.

5. Divine BJ, Barron V. Texaco mortality study: 11. patterns of mortality among white males by specific job groups. Am J Ind Med 1986;10:371—81

6. Maher KV, Defonso LR. A historical cohort study of mortality among chemical researchers. Arch Environ Health 1986;41: $109-16$.

7. Chiazze L, Wolf P, Ference LD. An historical cohort study of mortality among salaried research and development workers of the Allied Corporation. J Occup Med 1986;28:1185-8.

8. Dosemeci M, Alavanja M, Vetter R, Eaton B, Blair A. Mortality among laboratory workers employed at the US Department of Agriculture. Epidemiology 1992;3:258-61.

9. Burrows GE. Health care of people at work: screening of workers in research laboratories. J Soc Occup Med 1980;30: 164-8.

10. Hall A, Harrington JM, Aw TC. Mortality study of British pathologists. Am J Ind Med 1991;20:83-9.

11. Carpenter L, Beral V, Roman E, Swerdlow AJ, Davies G. Cancer in laboratory workers. Lancet 1991;338:1080-1.

12. Hunter WJ, Henman BA, Bertlett DM, Le Geyt IP. Mortality of professional chemists in England and Wales, 1965-1989. Am J Ind Med 1993;23:615-27.

13. Olin GR, Ahlbom A. The cancer mortality among Swedish chemists graduated during three decades: a comparison with the general population and with a cohort of architects. Environ Res 1980;22:154-61.

14. Belli S, Comba P, De Santis M, Grignoli M, Sasco AJ. Mortality study of workers employed by the Italian National Institute of Health 1960-1989. Scand J Work Environ Health 1992;18: 64-7.

15. Daly L, Herity B, Bourke GJ. An investigation of brain tumours and other malignancies in an agricultural research institute. Occup Environ Med 1994;51:295-8.

16. Pleven C, Audran R, Falcy M. Glioblastomes et mutagénèse chimique dans les laboratoires de biologie. Arch Mal Prof Med Trav Secur Soc 1983;44:411-8.

17. Rutty GN, Honavar M, Doshi B. Malignant glioma in laboratory workers. J Clin Pathol 1991;44:868-9.

18. Cordier S. Risk of cancer among laboratory workers. Lancet 1990;335:1097.

19. Coleman MP, Hermon C, Douglas A. Person-years (PYRS): a Fortran program for cohort study analysis. Lyon: International Agency for Research on Cancer, 1989. Internal report, no 89/ 006.

20. Checkoway H, Pearce N, Crawford-Brown DJ. Research methods in occupational epidemiology. New York (NY): Oxford University Press, 1989. Monographs in epidemiology and biostatistics, vol 13.

21. Breslow NE, Day NE. Statistical methods in cancer research vol 1 (The analysis of case-control studies). Lyon: International Agency for Research on Cancer, 1980. Scientific publications, no 32.

22. Cytel Software Corporation. StatXact: statistical software for exact non parametric inference, user manual. Cambridge (MA): CYTEL Software Corporation, 1989

23. Walter SD. Determination of significant relative risks and optimal sampling procedures in prospective and retrospective comparative studies of various sizes. Am J Epidemiol 1977; 105:387-97.

24. Benhamou E, Laplanche A, Wartelle M. Incidence des cancers en France 1978-1982: estimations France entière. Paris: Editions INSERM, 1990.

25. Olsson H, Brandt L. Risk of non-Hodgkin's lymphoma among men occupationally exposed to organic solvents. Scand J Work Environ Health 1988:14:246-51.

26. Blair A, Linos A, Stewart PA, Burmeister LF, Gibson R, Everett $G$, et al. Evaluation of risks of non-Hodgkin's lymphoma by occupation and industry exposures from a casecontrol study. Am J Ind Med 1993;23:301-12.

27. Kessler E, Brandt-Rauf PW. Occupational cancers of the brain and the bone. Occup Med 1987;2(1):155-63.

Received for publication: 9 March 1995. 